\title{
Evaluation of Interested Parties by Key Performance Indicators
}

\author{
Srđan B. STANOJKOVIĆ, Dragan CVETKOVIĆ
}

\begin{abstract}
Starting from the revision of the ISO 9001, the new version ISO 9001: 2015 was set up. About twenty key changes are made, but this paper deals with the concept of process as well as process performance indicators and measures to implement it. In this paper, key performance business indicators in graphic industry were consolidated. Measurement, analysis, improvement and their impact on the process are connected by unbreakable bond. By specifying the key performance indicators in this industry, the correct way for proper use and application of inputs (requirements, resources, energy) and outputs (finished product and by-products) in the business is explained. The quality standard ISO 9001:2015 was applied in this study.
\end{abstract}

Keywords: control map; graphic industry; interested parties; ISO 9001:2015; key performance indicators

\section{INTRODUCTION}

Interested parties (or stakeholders) build a business milieu on their own requirements and needs, thus affecting the social environment in a great extent. Adaptability to the business system is possible by harmonizing the goals of stakeholders at the highest level of organization and performance indicators of key business processes. The measurement of business performance by using GPI model and SPC statistical control of processes is enabled.

Improved version of ISO 9001:2008 is ISO 9001:2015 and its main characteristic is to promote business process approach. Comprehension of the organization's activities and actions is promoted by the new version of standard, and it represents the way how to manage the process itself.

In addition to the existing requirements, new activities are added and the organization is supposed to:

- establish the criteria, methods of measurement and process performance indicators;

- $\quad$ establish possible risks that could affect compliance between product services and customer satisfaction (if unintended products are delivered or if the operations among the processes are ineffective);

- determine the resources required for the functionality of process and ensure that the resources are available;

- assign responsibilities and authorizations necessary for processes. [6]

In order to manage the organization business process (eng. Business Process Management - BPM) that produces graphic products (books, brochures, notebooks, bags, sacks, boxes, paper, etc.), its key performance indicators should be identical to the key objectives of the organization.

It is necessary to define the objectives of key business processes in relation to the key factors of success, so that they could be controlled by the measurable key performance indicators (eng. Key Performance Indicators - KPI).

Hence, the business process is improving, as well as the measures of strategic performance. The process should be measured by a suitable model for the evaluation of KPI, with one or two indicators that characterize the specificity of activities within the organization that produces graphic products.

\section{PROCESS AND ISO 9001:2015}

"The process is a set of interconnected and interacting activities." [2]

The processes set up the values (not functions), both for the organization and for the users. Creating a process organization is a way to overcome problems of coordination among funcional units. This is the way to improve the bussines quality (by reducing processing time, increasing the quality of products and services, reducing redundant tasks). Process orientation of organization involves changes in the organization structure, organization focus (goals), system for performance measuring, and encroaches in proprietary relations as well as in relations with customers.

Process-oriented organization is an organizational form applicable in every organization. Visible novelty in standard ISO 9001: 2015 is the orientation of activities and specific requirements towards the adoption of a business process approach. In fact, this is a clear direction in the development, adoption, implementation and improvement of the quality management system (QMS) effectiveness in order to fulfill customers' satisfaction. [7]

Business process approach gives a clearer comprehension of the business process management, which contributes to the greater organizational effectiveness and efficiency. The result is the ability of organization to manage interdependence connections within the system, as well as improvement of the collective performance. Process approach enables systematic definition of process management and natural synergy between standards and its management system (QMS) in strategic orientations of an organization. Thus, system and process managemen tis realised through the PDCA cycle (Deming circle: Plan-Do-Check-Act). Business processes evaluation is "horizontaly" directed at the operational level, where the business takes place. [7]

By setting the process as a way of doing business, a significant innovation in the ISO 9001: 2015 is the obligatory appointment of responsible person for the process, so-called process owner. Based on that inovation, mandatory establishment of process performance indicators is implemented and these indicators are measured and monitored. Until now, organizations that have implemented QMS determined only few indicators (related to product realization processes-procurement, 
production and sale), that were necessary for certification. By making graphical presentation of business processes, which is recommendable, understanding of process business of an organization improves [6] (Fig. 1).

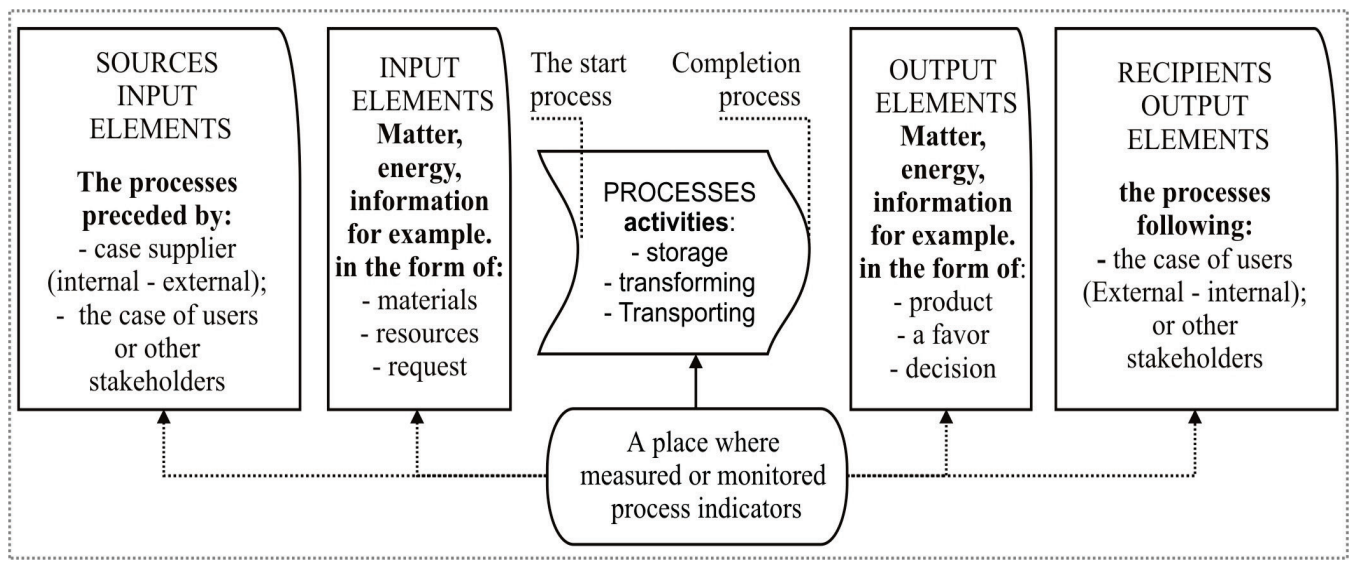

Figure 1 Graphic representation of general process model [7] (modified by the authors)

\section{KEY PERFORMANCE INDICATORS AND ISO 9001:2015}

Improvement of key business process quality is one of the requirements appointed by the enhanced standard and it has a major impact on the competitive advantages of an organization. Quality objectives can be considered as a part of business organization strategic goals.

The objectives of a business organization determine its tendency to achieve the vision and mission. They must be clear, measurable and visible to stakeholders.

The performance is the success or efficiency of an organization. There are two types of performances: the performance of the entire organization (ie. its impact or success); or process performance (performance or success of the process). They are measurable. Measures of performance are crucial characteristics of an organization. They "describe the quality of fulfillment of particular goal by usage of activities within the process or outputs of the process." (Hronec)

Indicators can be quantitative or qualitative. Degree or level of achievement of a given objective can be measured by these indicators, directly or indirectly.

Performance indicator is a measure of performance and it is used for estimation of objective realization progress. Process of monitoring and measurement of performance indicators is carried out in time, and the results serve as a basis for business improvement. [3]

The goal of ISO 9001:2015 is customers' satisfaction, and its requirements assess the progress by observing quality objectives and policy. For progress monitoring must be established process monitoring, measurement, analysis and improvement, which include:

- Establishment of key performance that should be monitored and measured permanently;

- Selection of appropriate key performance indicators for monitoring and measuring;

- Definition of methodology needed for monitoring, measurements, analysis and improvement.

The methods used to collect and analyze information about key performance indicators include:

- Monitoring and recording of process variables and product characteristics;

- Performance review, including suppliers and partners;
- Interviews, questionnaires, surveys on customer satisfaction and other stakeholders;

- Benchmarking (comparison with the second and best practice);

- Risk assessment and risk management;

- $\quad$ SPC techniques.

Key Performance Indicators of Organization (KPI) are factors which can be managed by an organization and that are critical to its sustained success. An organization should be enabled by KPI to:

- Set measurable objectives;

- Identify, monitor and predict trends in achieving the objectives;

- Take corrective, preventive and improvement measures when necessary.

Key performance indicators need to be identical to the key objectives of an organization. [3]

\subsection{GPI Model for Measurement of Key Performances}

Interested parties have a broader concept of the term stakeholders. Interested parties include stakeholders. [5]

Interested parties are "persons or groups that have an interest in the organization performance or success" (SRPS ISO 9004:2009). [10]

Stakeholders include:

- Interest entities related to the organization existence and functioning;

- Individuals or organizations that can achieve the profit or loss due to the success or failure of the system;

- People with an interest or stake in something (in the company);

- The participants, who carry out their activities in the system;

- Those who have rights or interests in the system;

- Individuals or groups who voluntarily (or not) succumb to the risk caused by company activities.

- Groups and all individuals who are affected by company activities, etc. [5]

The interested parties define goals of each business organization. If the objectives can be measured, the 
improvement of key business processes is possible thus achieving business goals. In this study, GPI model for key performances measuring was elected, as a model for the evaluation of KPI, their value and impact of specific objectives on the process quality. The condition for the application of this model is that there is a designed process model, which is the basis for process management. [8]

The structure of the GPI model for process key performance measuring is the following one:

- The objectives of the business system (Goals);

- Processes;

- Process performance indicators (Indicators).

It is recommended that every process should be measured by using KPI (with maximum three indicators that characterize its essential work) [6]. Corresponding process performance indicators should be modified according to the changes and development of environment and goals (strategies). Based on the general course of the organization, the general process that produces work subject is identified by organization accustomed acitivities. The entire business system consists of the following subsystems: business system that directly accomplishes the observed process "Manufacturing and Services" (basic activity) and mainly 12 subsystems (Marketing, Purchasing, Sales, Economics, Finance, Human Resources, Legal-normative, Management and Development, Quality and Information (sometimes Maintenance as well)) [8].

The process of the establishment of system for process performance measurements is:

- Definition of the organization's clear vision and mission;

- Identification of requirements of interested parties and their coversion into organization's measurable objectives;

- Identification of key processes needed for objectives' achievement (the KPI of the goal is measured);

- Conversion of the highest level goals into performance indicators of key processes that lead to the realization of previously set goals.

- Obtained results in this survey and GPI model for measurement of KPI make not only the basis for better performance business management, but for further researches in this field as well [8].

\subsection{Statistical Control Charts}

Method named Control chart is an effective tool for the process establishment, regulation and management. Its product is the quality of products and processes. This tool is used for: development and improvement of technological process and work; quality control processes and operations; phase control of product quality; analysis of system errors made during production process; in serial and mass production, etc. There are three main lines on control chart: central line CL (it represents nominal value, $X_{0}$ ); upper control limit line, GKG; lower control limit line, DKG. The control card can consist of two more lines above and below the upper and lower control limit (Fig. 2).

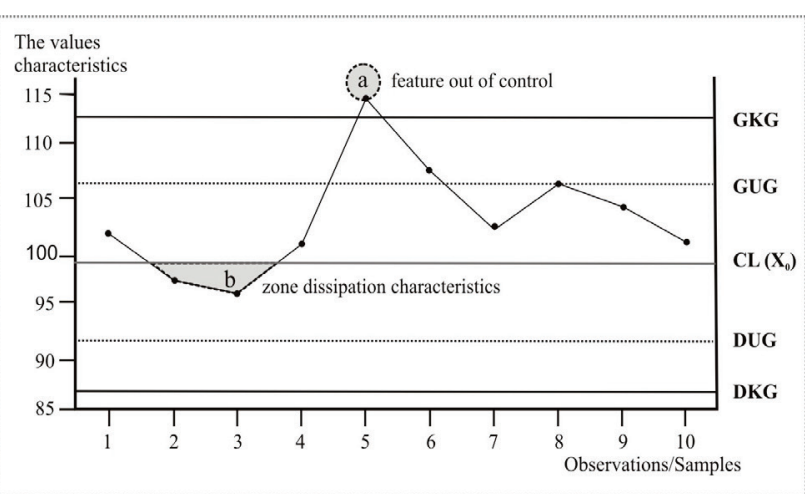

Figure 2 The generalized graphical representation of control charts [4]

They define the upper and lower warning limit (DUG and GUG) and represent values which indicate that the process tends to be unstable, or that more attention should be paid to the monitoring of the following measurements' results.

Generalized method for making control charts is the following one:

- Selection of object quality characteristics;

- Determination of dialing modes: sample size and time of sampling;

- Selection of statistical measures, which will be used for making the charts $(x, R, \sigma, p, m, c, u)$;

- Production of control charts' checklist. [5]

Basically, process control schedule is formed and it includes the time and location of sampling. Then comes the measurement of selected indicators' value and their characteristics, as well as their setting by required procedures and formulas. The results are entered in the control chart so that it becomes a transparent picture of quality in the time process duration (graphic is made). If obtained values are within the control limits (i.e., the control lines), it is considered that the process is stable (i.e., under statistical control). Otherwise, the process is unstable and out of the statistical control. [5]

\section{RESEARCH PROCESS}

The way of determining and evaluating key performance indicators in graphic organizations in this region is defined in the paper. The condition for this research was that the organizations had implemented business process approach. The principle of qualitative research based on the small sample method (up to 40 sampled facilities) was applied. The survey was conducted by using a questionnaire. The business of an organization was observed as a process and obtained values were statistically processed by method for process analysis named control chart. Eventually, values obtained by statistical method were added to key performance indicators (KPI) and organization goals. Evaluation of requirements of interested parties was done by final calculation.

Examination and data collection are enabled by application of the criteria of $\mathrm{MH}$ model of excellence. A method for determination of key performance business indicators in graphic industry is the GPI model for the measurement of process performances. Measurability and graphical representation of survey data are given by 
statistical method named control charts. Excel was used for calculation and table preparation, and Corel DRAW was used for graphical representation and drawing.

\section{THE COURSE OF STUDY}

In the first phase of the research, stakeholders are defined through their objectives and key processes that are specific for graphic industry. The stakeholders' requirements and compared goals of graphic industry are classified in two levels as primary and secondary goals. The classification is based on the core business of graphic organizations (by decompensation process of objectives and strategies).

Goals generalization has enabled the specificity of operations in graphic industry by using criteria of $\mathrm{MH}$ model of excellence. Since the MH model can be easily adapted to environment changes, for this research were used its criteria and subcriteria based on EFQM and RADAR matrices, that have flexible ponderation and percentage estimation values $(0-100 \%$ for each criterionobjective). Thus, measuring instruments for all indicators were made. They were monitored and measured and the report about achieved results was made (in order to compare them with previously defined indicators) [1].

In the second phase, representatives of leading graphic organizations from this region were interviewed by questionnaires. Business of the organization was observed as a process and sampled values were statistically processed by control chart for the process analysis.

A table for conversion of objectives into process performance indicators in Serbian graphic industry was made in the third phase of this research. Goals at both levels, key processes for their realization and KPI for the realization measuring were marked in the table [8] (Fig. 4). After conversion of the objectives into performance indicators was done, values processed by statistical method named control chart were added to each set within the GPI table (appropriate objectives and key processes).

In the final phase, results of each objective and corresponding statistical measurement values are joined, thus giving connecting points for generalized diagram with columns. It represents the business process success with clear hierarchy of importance of selected goals, business indicators for key performance in graphic industry and their levels in the business system. Thereby, the evaluation of requirements of interested parties was done [4, 8].

\subsection{Functions, Objectives and Evaluation of Interested Parties}

Respondents were representatives of leading graphic organizations in this region and they were orally answering questions from the questionnaire.

Questionnaire was based on 12 criteria of MH model of excellence [1]. Each criterion had its own sub-criteria that represented (in this case) the function between questions and allegations. They were evaluated according to the check list $(0-100 \%)$, and the questionnaire contained 960 questions. Questions were processed by the method named control chart. Afterwards, they were incorporated into collective control charts with a clear hierarchy of key performance indicators in graphic industry located in this region. Table content for the sample was processed by statistical method named control chart (Fig. 3).

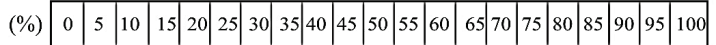

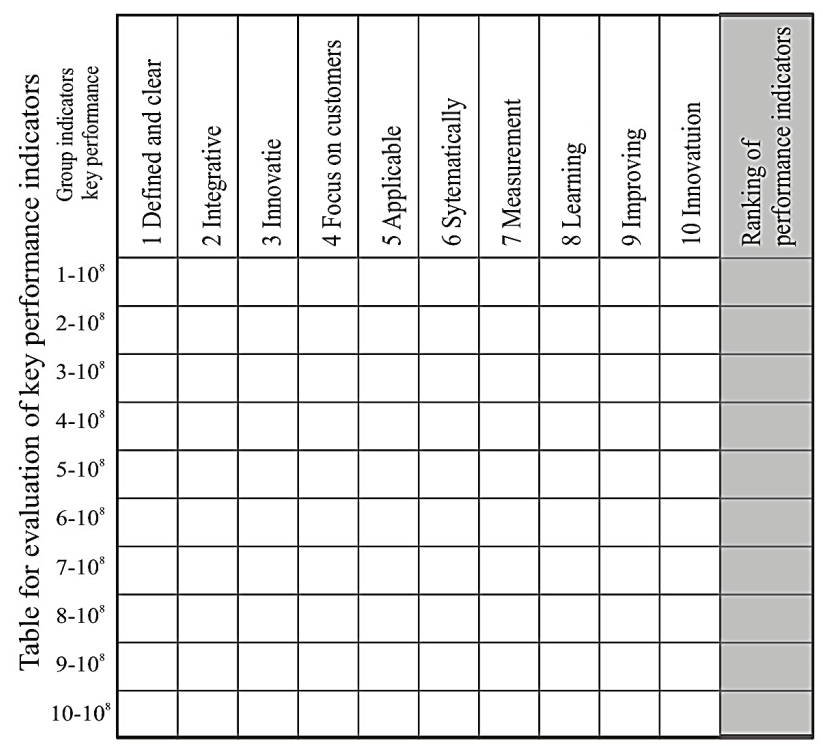

Figure 3 Table for data collection used for measurement of key performances in graphic industry in Serbia [1, 2]

Fifty questions were framed in order to make the table for conversion of the objectives into the process performance indicators in Serbian graphic industry. These questions were processed by samples shown in Fig. 4. The questions were formulated analogically with the previously mentioned method named control chart.

Summary results show the content of denominators that are used in the table in Fig. 5. This table serves to convert organization's objectives into business performance indicators.

Defined interested parties (and stakeholders) are: the user (customer), the owner (three forms: paper processing, book binding, packages production), employees, the state and local communities. Their general objectives are evaluated with value of 1 .

The criteria of MH model of excellence are impelemented as organizational objectives and they are evaluated by the statistical method (control chart) as follows: leadership $(0,79)$, processes $(0,82)$, development of vision and strategy $(0,79)$, customer and partnership marketing $(0,78)$, people $(0,80)$, resources $(0,79)$, continuous improvement and innovation $(0,80)$.

The key processes are evaluated in the same way and they are consisted of: manufacture and products $(0,76)$, development of the relations with customers $(0,81)$, human resources $(0,74)$, attitude towards company $(0,79)$, key results analysis $(0,80)$.

\subsection{Conversion of the Objectives into Process Performance Indicators}

Objectives of business system are defined in accordance with requirements of interested parties (Level I, strategically), and put in the GPI model table. Afterwards, they are converted into the objectives of lower hierarchical level (Level II), decomposed and at the end connected to the process key performance indicators. Previously defined goals of an organization are realized with the realization of process key performance indicators. The level of accomplishment of objectives and 
missions of an organization is determined by measurement of process performance indicators and their comparison to previously defined goals. Achieved relations are increased by statistical method value, thus giving the evaluation of stakeholders' requirements that is shown in the diagram with columns.

\begin{tabular}{|c|c|c|c|c|c|c|c|c|}
\hline \multirow{3}{*}{ 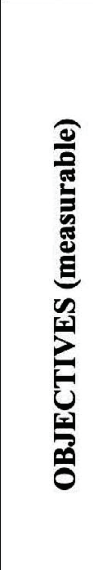 } & 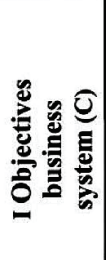 & $\begin{array}{l}\text { Beneficiary } \\
\text { (customer) }\end{array}$ & $\begin{array}{c}\text { I-The owner } \\
\text { (processing } \\
\text { paper) }\end{array}$ & $\begin{array}{c}\text { II-The owner } \\
\text { (paper } \\
\text { packaging) }\end{array}$ & $\begin{array}{c}\text { III-The owner } \\
\text { (Bookkeeping. } \\
\text { Products)) }\end{array}$ & Workpeople & Country & $\begin{array}{c}\text { Local } \\
\text { community }\end{array}$ \\
\hline & 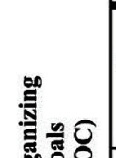 & 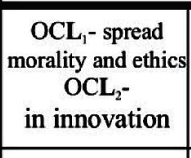 & $\begin{array}{c}\mathrm{OCP}_{1} \text { - generation } \\
\text { process } \\
\text { OCP }_{2} \text { - Promote } \\
\text { the Bye process }\end{array}$ & $\begin{array}{c}\text { OCR }- \\
\text { formulation } \\
\text { OCR }_{2}-\text { translation } \\
\text { the objectives }\end{array}$ & $\begin{array}{c}\mathrm{OCM}_{1} \text {-conquest } \\
\text { new markets } \\
\text { OCM }- \text { an increase } \\
\text { the number of } \\
\text { customers }\end{array}$ & $\begin{array}{c}\text { OCL } \mathbf{J}_{1} \text { - developmen } \\
\text { employee } \\
\text { OCL } \mathbf{L} \mathbf{J}_{2} \text { - recognition } \\
\text { needs of employees }\end{array}$ & $\begin{array}{c}\text { OCR } \text {-sustainable } \\
\text { development } \\
\text { OCR } \\
\text { procecycling } \\
\text { procedures }\end{array}$ & $\begin{array}{c}\text { OCPI }_{1-}^{-} \\
\text {growth improving } \\
\text { OCPI }_{2^{-}} \\
\text {in innovation }\end{array}$ \\
\hline & है & Leadership & Processes & $\begin{array}{l}\text { Development } \\
\text { vision and } \\
\text { strategy }\end{array}$ & $\begin{array}{c}\text { Marketing } \\
\text { customer and } \\
\text { partnerships }\end{array}$ & People & Resources & $\begin{array}{c}\text { Continual } \\
\text { improvements } \\
\text { and innovation }\end{array}$ \\
\hline
\end{tabular}

\begin{tabular}{|c|c|c|c|c|c|}
\hline & \multicolumn{5}{|c|}{$\begin{array}{l}\text { TRANSLATION OF GOALS BUSINESS SYSTEM process performance indicators } \\
\text { - RECOGNITION INTERDEPENDENCE objectives and processes - }\end{array}$} \\
\hline $\begin{array}{l}\text { INDICATORS } \\
\text { PROCESS } \\
\text { (I) }\end{array}$ & $\begin{array}{l}\mathrm{IP}_{1}-\text { development } \\
\text { new products } \\
\mathrm{IP}_{2} \text { - improvement } \\
\text { old products }\end{array}$ & $\begin{array}{l}\text { IRk } \mathbf{k}_{1} \text { - measuring } \\
\text { customer opinions } \\
\text { IRk } \mathbf{k}_{2} \text { - measuring } \\
\text { performances } \\
\text { Innovations }\end{array}$ & $\begin{array}{c}\text { Iolj }_{1} \text { - measuring } \\
\text { customer opinions } \\
\text { Iolj } \mathbf{j}_{2} \text { - measuring } \\
\text { performances } \\
\text { Innovations }\end{array}$ & $\begin{array}{l}\text { IOd }- \text {-fulfillment } \\
\text { legal obligations } \\
\text { IOd }- \text { Reduction } \\
\text { and damage caused } \\
\text { by its processes }\end{array}$ & $\begin{array}{c}\mathbf{I K} \mathbf{r}_{1} \text {-performance } \\
\text { Key outputs } \\
\mathbf{I} \mathbf{k r}_{2} \text { - performance } \\
\text { key results }\end{array}$ \\
\hline $\begin{array}{l}\text { KEY } \\
\text { PROCESSES }\end{array}$ & $\begin{array}{l}\text { Production } \\
\text { (Products) }\end{array}$ & $\begin{array}{l}\text { Development of } \\
\text { relations to customers }\end{array}$ & $\begin{array}{l}\text { Relations } \\
\text { to people }\end{array}$ & $\begin{array}{l}\text { Relations } \\
\text { to society }\end{array}$ & $\begin{array}{l}\text { Analysis of key } \\
\text { results }\end{array}$ \\
\hline
\end{tabular}

Figure 4 Tables for conversion of the objectives into process performance indicators in graphic industry in Serbia [8, 11] (modified by authors)

The overall course and layout of the conversion of process performance objectives, calculation and evaluation of requirements of stakeholders is shown in Fig. 5.

$$
\mathrm{CK}_{\mathrm{n}}=\left[\Sigma_{\mathrm{n}}(\mathrm{I}+\mathrm{II})+(\mathrm{I}+\mathrm{In})\right]+\Sigma_{\mathrm{n}}(\mathrm{II}+\mathrm{In})
$$

Where the interested party User-buyer: $\mathrm{CK}_{\mathrm{n}}$ - all the goals User-buyer $\left(\mathrm{CK}_{1}, \mathrm{CK}_{2}, \mathrm{Ck}_{3}\right)$;

I - level business objectives of the system; II - second-level organizational objectives (decompensated); In - indicators of key processes.

$\mathrm{CK}_{1}(\mathrm{I}+\mathrm{II})=\mathrm{OCL}_{2}+\mathrm{OCP}_{1}+\mathrm{OCP}_{2}+\mathrm{OCR}_{1}+\mathrm{OCLJ}_{1}+\mathrm{OCPI}_{1}$ evaluation - $0,79+0,82+0,82+0,79+0,80+0,80$

$$
\mathrm{CK}_{1}(\mathrm{I}+\mathrm{II})=4,82
$$

$\mathrm{CK}_{1}(\mathrm{I}+\mathrm{In})=\mathrm{IP}_{1}+\mathrm{IP}_{2}+\mathrm{IRk}_{1}+\mathrm{IKR}_{2}$ evaluation $-0,76+0,76+0,81+0,80$ $\mathrm{CK}_{1}(\mathrm{I}+\mathrm{In})=3,13$

$\mathrm{CK}_{1}$ (quality) $=4,82+3,13=7,95$

$$
\mathrm{CK}_{1}=7,95 \ldots
$$

$\mathrm{CK}_{1}=7,95, \mathrm{CK}_{2}=8,61, \mathrm{CK}_{3}=17,36$

$$
\begin{aligned}
& \Sigma_{1-7} \text { quality }(\mathrm{II}+\mathrm{In})=30,25 \\
& \mathrm{CK}_{1,2,3}=33,92+30,25=64,17 \\
& \mathrm{CK}=\mathbf{6 4 , 1 7} \text { User-buyer }
\end{aligned}
$$

Figure 5 Example of performance objectives conversion cours, estimation of multiplication value and evaluation of requirements of interested parties $[8,11]$

The calculation for every group of stakeholders should be done by using the results obtained due to the statistical method named control chart and data from GPI table. Primarily, first and second-level goals should be connected, then the first-level objectives are associated with respondent indicators. Finally, the second-level objectives are converted into corresponding indicators. At the same time, each element (the goal or the indicator) gets a value of statistical calculation. Thus, the values of stakeholders are evaluated in the sum. The diagram with columns is shown in Fig. 6.

\subsection{Research Summary Results}

In this study, 7650 collected characteristics are processed by statistical metod named control chart and 450 collected characteristics by GPI method.

Their processing led to the result that evaluates the requirements of stakeholders as follows:

- The user (customer), was evaluated with 64,17 points;

- The owner, who processes the paper (hand towels, napkins, notebooks etc.), was evaluated with 56,65 points;

- The owner, who produces packages (bags, sacks, boxes, etc.), was evaluated with 50,99 points;

- The owner, who produces bookbinding products (brochures, books, blocks, etc.), was evaluated with 63,23 points;

- Employees were evaluated with 35,20 points;

- The country was evaluated with 23,49 points;

- The local community was evaluated with 21,99 points. 
Clear hierarchy of various stakeholders engagements and participations in the functioning of graphic industry in Serbia is more than obvious. The biggest engagement is shown by product and service users, as well as by owners (service providers or manufacturers). Involvement of employees and the state is significantly lower, while local communities have the lowest participation.

Established evaluation of stakeholders' requirements is presented in Fig. 6.

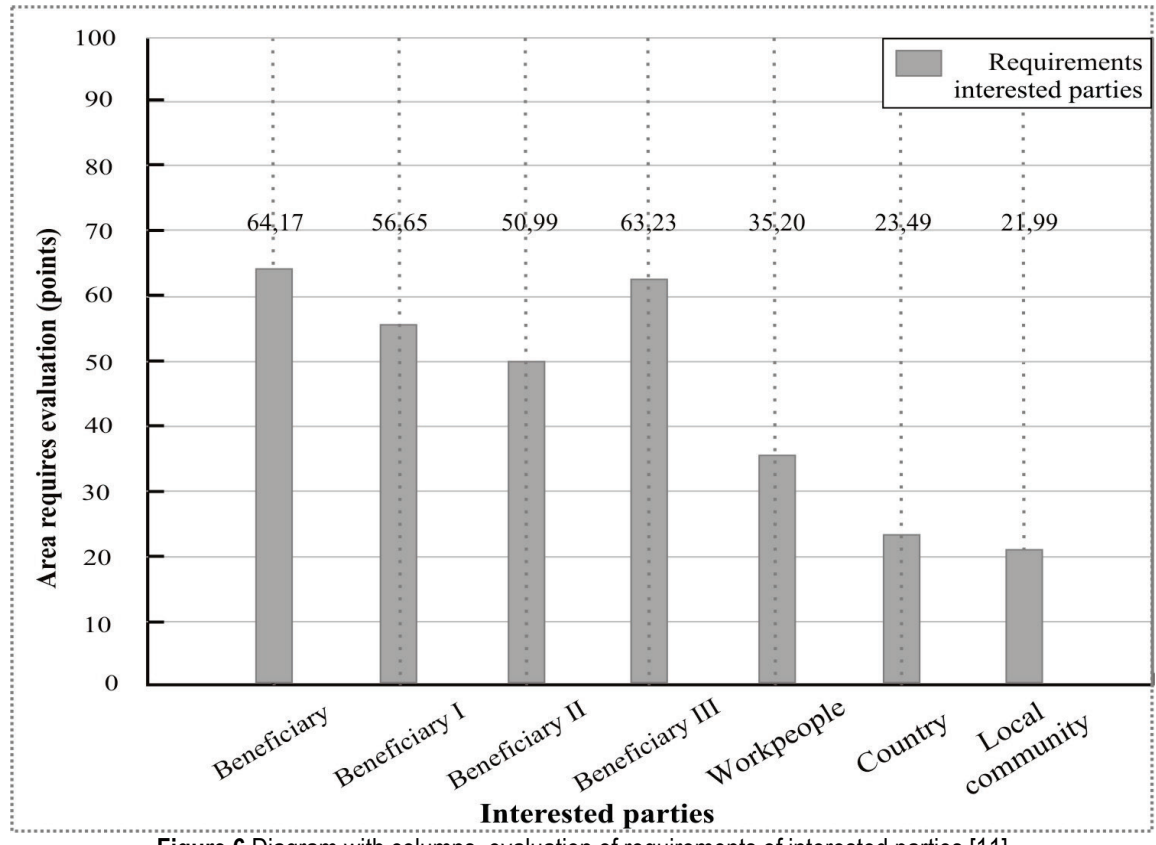

Figure 6 Diagram with columns, evaluation of requirements of interested parties [11]

\section{CONCLUSION}

GPI model enables rapid adaptation to changes that are inevitable in a business environment. Process performance indicators are easily adjusting by changing the business system goals. These indicators are some kind of guidelines which serve to monitor the fulfillment of previously defined objectives. A practical way that can be used to define the importance of professionalism and state of graphic industry in Serbia is shown by using key performance indicators in evaluation process of requirements of interested parties. It is important to note that key processes and indicators, which were used in calculation and usage of GPI model, are changing with the modification of business environment.

Discussion of the obtained values and the importance of stakeholders in the research are the topic of some further researches.

\section{REFERENCES}

[1] Heleta, M. (2010). TQM Modeli izvrsnosti i integrisani menadžment sistemi, Zavod za udžbenike Beograd

[2] Heleta, M. (2008). Menandžment kvaliteta, Univerzitet Singidunum, Beograd

[3] Heleta, M. (2012). Projektovanje menadžment sistema kvaliteta, Univerzitet Singidunum, Beograd

[4] Kostić, M. (2004). Metode i tehnike za poboljšanje kvaliteta, Beogradski univerzitet, Beograd

[5] Stanojković, S. (2014). Modeli izvrsnosti i samoocenjivanje $u$ grafičkoj industriji Srbije, Univerzitet Singidunum, Beograd

[6] Milovanov, B. (2013), 20 ključnih izmena u standardu ISO CD 9001:2015, http://www.kvaliteta.net/files/
20 KLJUCNIH IZMENA U STANDARDU ISO CD 9 001-2015_-_Branislava_Milovanov.pdf

[7] SRPSISO 9001:2015. Sistemi menadžmenta kvalitetom, http://www.iss.rs/standard/?natstandard_document_id=502 55

[8] Simeunović B. P. (2015) Razvoj modela za merenje performansi procesa, Fakultet organizacionih nauka, Univerzitet u Beogradu, https://fedorabg.bg.ac.rs/fedora/ get/o:11191/bdef:Content/download

[9] Kipphan, H. (2000). Handbook of Print Media, Heidelberger Druckmaschinen AG Heidelberg.

[10] SRPS ISO 9004:2009. Rukovođenje sa ciljem ostvarivanja održivog uspeha organizacije - Pristup preko menadžmenta kvalitetom - Zahtevi, ISS, Beograd, www.iss.rs/standard/?natstandard document id $=24002$

[11] Brekalo, S. (2015). Optimizacija digitalne grafičke pripreme korišćenjem skriptnih jezika, http://eprints.grf.unizg.hr/2448/1/Doktorski_rad_Brekalo_S anja.pdf

\section{Contact information}

Dragan CVETKOVIĆ,

Uniuverzitet Singidunum,

Danijelova 32, 11000 Beograd, Serbia

dcvetkovic@singidunum.ac.rs

\section{Srđan B. STANOJKOVIĆ}

Beogradska politehnika,

Katarine Ambrozić 3, 11000 Beograd, Serbia

sstanojkovic@politehnika.edu.rs 